\title{
THE EFFECT OF A BIOPREPARATION ON LEGUME (PISUM SATIVUM)
}

\author{
Martynenko V.V., Rysbek A.B., Kurmanbayev A.A., Baigonusova Zh.A. \\ National Center for Biotechnology \\ 13/5, Korgalzhyn road, Nur-Sultan, 010000, Kazakhstan \\ vitalya2497@gmail.com
}

\begin{abstract}
A field experiment of a biological preparation based on the association of nitrogenfixing bacteria was carried out. The composition includes active and compatible strains of nitrogen-fixing and nodule bacteria. As a result, the biological preparation had a positive effect on germination, length and vegetative mass of peas. The results of research indicate the perspective of the industrially valuable strains of this association. Optimal conditions for the work of the biological preparation are light mechanical composition of the soil and the provision of moisture during the growing season of plants. This preparation may be recommended for use in the Northern regions of Kazakhstan.

Key words: biological preparation, nitrogen-fixing bacteria, peas, bacterial associations, productivity.

\section{INTRODUCTION}

Bacterial fertilizers allow you to take the natural potential of environment to improve mineral nutrition and plant protection. They are completely safe for humans and the environment, exclude environmental risks and make it possible to reduce the doses of applied agrochemicals and mineral fertilizers. The goal of this work is to create a biological product that increases the yield of legumes.
\end{abstract}

\section{Materials and methods}

The cultivation of strains of nitrogen-fixing bacteria was carried out in a modified Burke's medium on a rotary shaker at $180-200 \mathrm{rpm}$ and $28{ }^{\circ} \mathrm{C}$ for 48 hours [1]. The biological compatibility of bacteria was established by the method of Kiryushin [2] and Kovalevskaya [3]. Field experiments were laid on stubble of field № 5. Soft spring wheat was the predecessor. Field preparation and implementation of experiments are carried out according to the relevant recommendations of Kazakh Scientific Research Institute of Grain Farming [4, 5], with some additions and changes accepted at the Research and Production Center of grain farming named after A.I. Baraev.

\section{RESULTS}

The composition of the biological preparation for legumes included an association of microorganisms (Rhizobium sp. Strain Rh-1 + Azotobacter chrooccocum strain Az $34+$ Agrobacterium sp. Strain Az $6+$ Agrobacterium sp. Strain Az 4). The ratio in the association is 7: 1:1: 1, which ensures its stable work due to the symbiotic relationship of microorganisms.

To assess the effectiveness of biological preparation was conducted experiment on the fields of the Research and Production Center of grain farming named after A.I. Baraev on an area of $300,000 \mathrm{~m}^{2}$ (Figure 1). For pre-sowing treatment, 10 liters of suspension concentrate $\left(10^{9}\right.$ 
$\mathrm{CFU} / \mathrm{ml}$ ) were used. The biological preparation was diluted five times to treat $6000 \mathrm{~kg}$ of pea seeds of the "Aksai Usatii-55" variety.

The growing season for peas in the field experiment was 86 days on average. The period from germination to flowering was 36-37 days for the studied samples. In the experimental field, there was not a complete harvest yet, because the ripening of peas was delayed due to the dry of 1-2 decades. However, in the experiment and control variants maturation was uneven.
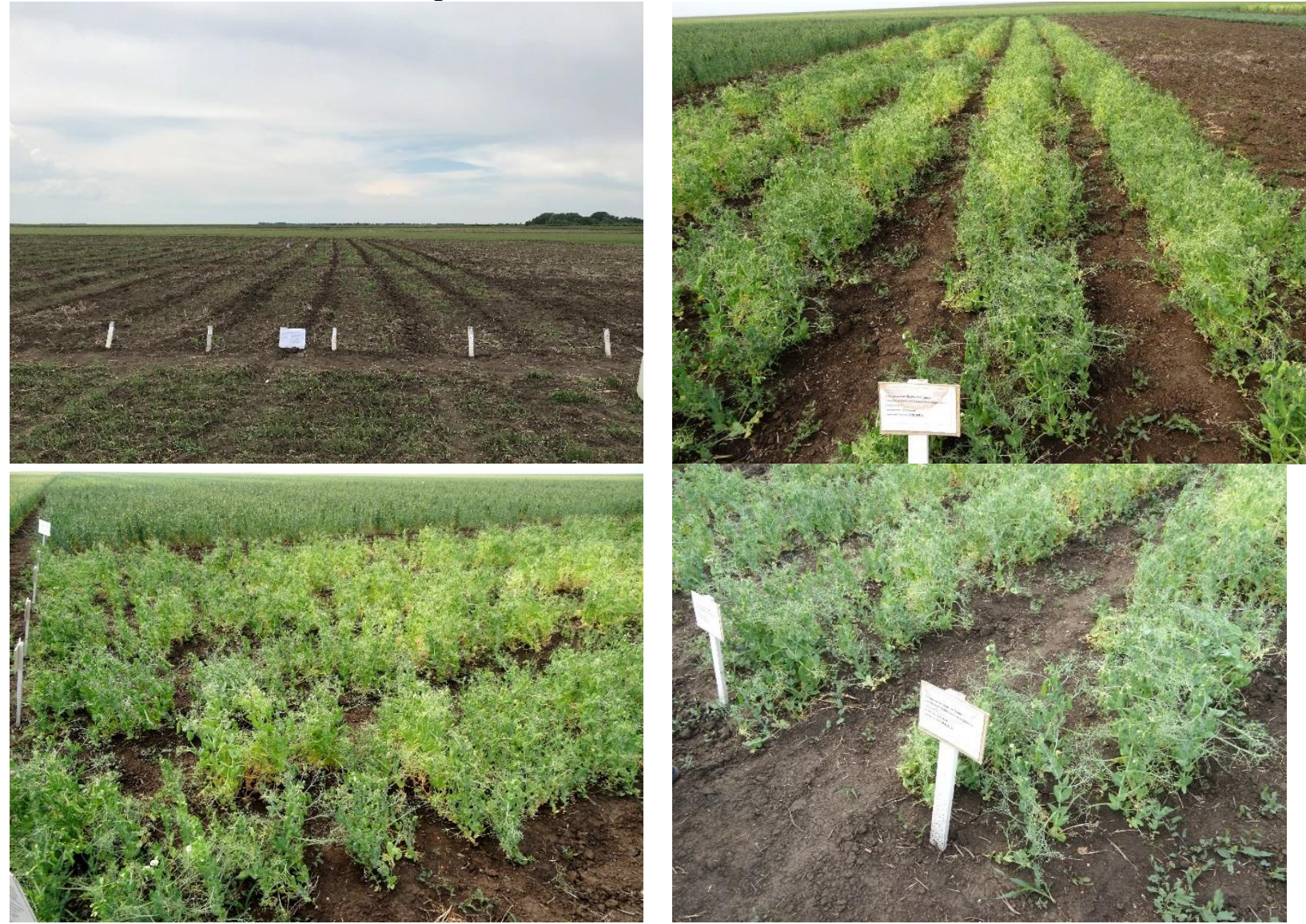

Fig. 1. Research of the influence of biological preparation on the yield of peas on the experimental fields of the Research and Production Center of grain farming named after A.I. Baraev

\section{DISCUSSION}

Despite the unfavorable weather and soil conditions, the biological preparation provided an increase in the grain yield of peas of the "Aksaysky Usatii 55" variety by 1.38 centner/ha compared to the control variant. The structural indicators of pea plants also demonstrate the effectiveness of the preparation: early flowering, the plant height is $15.4 \mathrm{~cm}$ higher than in the control variant; the number of seeds per plant was 141.03, and the weight of seeds per plant was $198.2 \mathrm{~g}$; while in control - 116.38 pcs. with weight of $190.2 \mathrm{~g}$.

\section{CONCLUSIONS}

Thus, according to the results of the field experiment, the biological preparation provided the grain yield of peas equal to 13.00 centner/ha, which exceeded the control variant without treatment by $12 \%$.

\section{Acknowledgments}


This work was supported by the Ministry of Agriculture of the Republic of Kazakhstan (STP BR06349586).

\title{
REFERENCES
}

1. Ibatullina R.P. Ekologicheskie aspekty primeneniya biopreparatov $v$ Respublike Tatarstan. Avtoref. kand. biol. nauk [Environmental aspects of the use of biological preparations in the Republic of Tatarstan Cand. biol. sci. ref.]. Kazan, 2011. 24 p.

2. Kiryushin B.D., Usmanov R.R., Vasilev I.T. Osnovy nauchnyh issledovanij v agronomii [Fundamentals of scientific research in agronomy]. Moscow, Kolos Publ., 2009. 398 p.

3. Kovalevskaya V.S., Molodkina N.R., Timofeenko T.I. Izuchenie biosovmestimosti $i$ biotekhnologicheskih svojstv molochnokislyh bakterij [The study of biocompatibility and biotechnological properties of lactic acid bacteria]. Nauchnye trudy KubGTU [Proc. of the KubGTU], 2016, no 14, pp. 284-288.

4. Sistema zemledelija opytnogo hozjajstva [The pilot farming system]. Vserossijskij nauchno-issledovatelskij institut zernovogo hozjajstva im. A.I Baraeva - All-Russian Scientific Research Institute of Grain Farming named after A.I. Baraev, Shortandy, 1986. pp. 4-6.

5. Korsakov N.I., Adamova O.P., Budanova V.I. Metodicheskie instrukcii dlja izuchenija kollekcij zernovyh bobovyh kultur [Methodological instructions for studying the collections of grain legumes]. Leningrad: VIR, 1975. 59 p.

\section{БҰРШАҚ ДАҚЫЛДАРЫНА (PISUM SATIVUM) АРНАЛҒАН БИОЛОГИЯЛЫқ ӨНІМ}

\author{
Мартыненко В. В., Рысбек А.Б., Курманбаев А.А., Байгонусова Ж.А. \\ Ұлттық биотехнология ортальгы \\ Қорвалжын тас жольы, 13/5, Нұр-Сұлтан, Қазақсттан \\ vitalya2497@gmail.com
}

\section{ТYЙІН}

Азотфиксациялаушы бактериялар қауымдастығы негізінде биологиялық өнімнің далалық эксперименті жүргізілді. Препараттың құрамына азотфиксациялаушы және түйнекті бактериялардың белсенді және үйлесімді штамдары кіреді. Зерттеу нәтижесінде биологиялық өнім бұршақтың өнуіне, ұзындығына және вегетативті массасына оң әсер ететіні анықталды. Алынған нәтижелер осы қауымдастықтың өндірістік және құнды штамдар екенін көрсетті. Биопрепараттың тиімді жұмыс істеуі үшін оңтайлы жағдайлар, топырақтың механикалық құрамы бойынша жеңіл және өсімдіктердің өсіп келе жатқан кезеңінде ылғалдылықты қамтамасыз етуі тиіс. Бұл препарат Қазақстанның солтүстік өңірлерінде қолдану үшін ұсынылуы мүмкін.

Негізгі сөздер: биопрепарат, азотфиксирлеуші бактериялар, бұршақ, бактериялар қауымдастығы, өнімділік 


\section{ВЛИЯНИЕ БИОПРЕПАРАТА НА БОБОВУЮ КУЛЬТУРУ (PISUM SATIVUM)}

Мартыненко В. В., Рысбек А.Б., Курманбаев А.А., Байгонусова Ж.А.

Нацииональный цеентр биотехнологии

Кургальжинское шоссе, 13/5, Нур-Султан, 010000, Казахстан

vitalya2497@gmail.com

АБСТРАКТ

Был проведен полевой эксперимент биопрепарата на основе ассоциации азотфиксирующих бактерий. В состав препарата входят активные и совместимые между собой штаммы азотфиксирующих и клубеньковых бактерий. В результате исследования было установлено, что биопрепарат оказывает положительное влияние на всхожесть, длину и вегетативную массу гороха. Полученные результаты свидетельствуют о перспективности производственно-ценных штаммов из данной ассоциации. Оптимальными условиями для эффективной работы биопрепарата являются легкие по механическому составу почвы и обеспечение влажности во время вегетации растений. Данный препарат может быть рекомендован для применения в Северных регионах Казахстана.

Ключевые слова: биопрепарат, азотфиксирующие бактерии, горох, ассоциации бактерий, урожайность. 